D.B. Moore-Shedrow, Manager

Authorized Derivative Classifier

THE CONCENTRATION OF RADIONUCLIDES AND METALS IN VEGETATION ADJACENT TO AND IN THE SRL SEEPAGE BASINS (U)

Charles E. Murphy Jr.

Publication Date: December 14, 1992

Approved By: D.B. Moore, Manager

Environmental Sciences Section

Savannah River Laboratory

Westinghouse Savannah River Company

Savannah River Site

Aiken, SC 29808

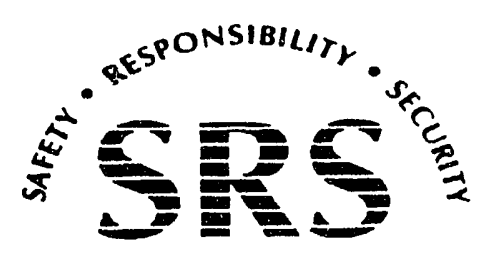

SAVANNAH RIVER SITE

THIS DOCUMENT WAS PREPARED IN CONNECTION WITH WORK UNDER THE U.S. DEPARTMENT OF ENERGY (CONTRACT DE-AC09-89SR18035).

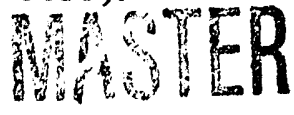

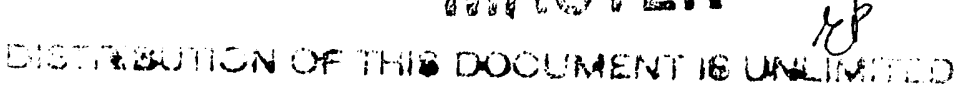


ABSTRACT 1

INTRODUCTION ................................................................................................. 1

Description ............................................................................................................. 2

History of Operation .......................................................................................... 3

Soil Concentrations .............................................................................................. 3

Description of Sampling Sites................................................................... 3

Differences between Basins .................................................................. 4

Variation with Depth ................................................................................ 5

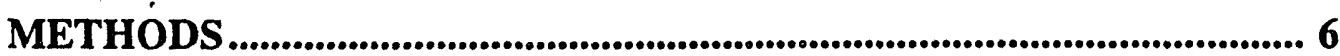

Sampling ............................................................................................................. 6

Analysis ......................................................................................................... 6

Preparation ............................................................................................ 6

Radionuclides ................................................................................. 6

Metals ............................................................................................ 7

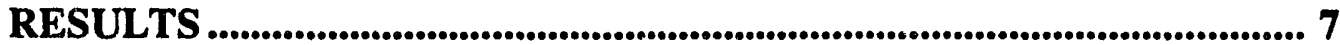

Comparison of Leaves and Wood ............................................................. 7

Comparison of Pines and Hardwoods .................................................... 8

Relationship of Location to Concentration .......................................... 9

Vegetation /Soil Concentration Ratios ................................................ 10

Vegetation on the Bottom of Basin Four .......................................... 10

Vegetation on the Edge of the Basins ..................................................... 12

Estimation of Total Radionuclides and Metallic

Elements in the Vegetation ................................................................... 13

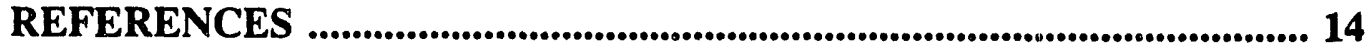

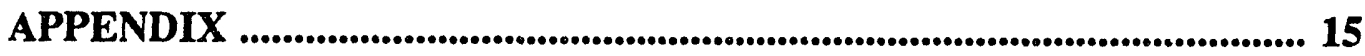


1. Layout and Sampling Scheme for Collection of Vegetation

from the SRL Seenage Basins. 2

2. Distribution of Radionuclides among Basins (Waste-Water

entered at Basin 1 and only rarely reached Basin 4)...........................4

3. The Decrease in ${ }^{137} \mathrm{Cs}$ with Distance from the Surface...............................................5

4. The Slope (Logarithmic) of Contaminant Concentration versus

Distance from the Surface in Each Basin. .5

5. Relationship of Leaf to Wood Concentration for Strontium-90. 7

6. The Effect of Location on Average Radionulcide Contaminant

Concentrations in Basin 4. 9

7. The Effect of Location on Average Metallic Contaminant

Concentrations in Basin 4. .9

8. Vegetation/Soil Concentration Ratios for Trees growing in the

Sediments of Basin 4. 11

9. Geometric Mean Vegetation/Soil Concentration Ratios for Trees

growing on the Edge of All the Basins.

\section{LIST OF TABLES}

1. The Dimensions and Approximate Capacity of the

SRL Seepage Basins. 2

2. Radioactive Releases to the SRL Seepage Basins

from 1958 to 1980 (DPSTD-84-110)....................................................... 3

3. Estimated Releases of Selected Metals (DPSTD-84-110). ...................................... 4

4. Ratio of Concentration in Leaves to Concentration in Wood. .................................... 8

5. Ratio of Concentrations in Hardwood/Pine in Basin 4. ............................................... 8

6. Concentration Ratios Measured at SRI Seepage

Basins and a Literature Survey. .............................................................. 11

7. Total Contaminants in SRL Seepage Basin Trees. ................................................... 13

8. Radionclide Concentrations (pCi/gm-dry) in Trees from the SRL Seepage Basins. ........................................................................... 16

9. Metal Concentrations ( $\mathrm{mg} / \mathrm{kgm}-\mathrm{dry}$ ) in Trees from the SRL Seepage Basins. ................................................................. 18 


\title{
THE CONCENTRATION OF RADIONUCLIDES AND METALS IN VEGETATION ADJACENT TO AND IN THE SRL SEEPAGE BASINS
}

by

\author{
Charles E. Murphy Jr. \\ Savannah River Technology Center \\ Aiken, S.C.
}

\begin{abstract}
In 1991 the trees on the dikes surrounding the SRL Seepage Basins were sampled and analyzed to inventory the contaminants transported from the basins into the vegetation. Tree leaves and wood were collected and analyzed for ${ }^{90} \mathrm{Sr},{ }^{60} \mathrm{Co},{ }^{137} \mathrm{Cs},{ }^{238} \mathrm{Pu}, 239,240 \mathrm{Pu}, 242,244 \mathrm{Cm},{ }^{241} \mathrm{Am}, \mathrm{Ba}, \mathrm{Cr}, \mathrm{Hg}, \mathrm{Mg}$, $\mathrm{Mn}, \mathrm{Ni}$, and $\mathrm{Pb}$. The concentrations of contaminants were influenced by sample type (leaves versus wood), species type (pines versus hardwoods), and location relative to distance from the basin.

The concentration in the vegetation and the sediments were used to calculated concentration ratios for trees growing on the sediments in the bottom of Basin 4, the only basin that was not flooded with water. With the exception of $\mathrm{Mg}, \mathrm{Cr}$, and $\mathrm{Ba}$, which are significantly higher, the concentration ratios all fall within the range of previously determined ratios reported in the literature; however, in some cases the mean concentration ratio measured at the SRL Basins is higher than the mean literature values.

Concentration ratios were also calculated for the trees growing on the edge of all four basins. The mean concentration ratios for the contaminants in trees growing at the edge of the basin reflected both the effect of type of contaminant and location, as seen in Basin 4. Ba, $90 \mathrm{Sr}, \mathrm{Mg}$, and $\mathrm{Mn}$ have high concentration ratios similar to those found in the trees growing directly on the sediments. This suggests a relatively high mobility and transport of these materials through roots extending under the basin.. Other contaminants, such as ${ }^{137} \mathrm{Cs}$, Pu isotopes, and ${ }^{241} \mathrm{Am}$ have lower concentration ratios for the trees growing on the edge of the Basins than for trees growing in the bottom of the basin, suggesting that these contaminants are less mobile.

The total inventory of each contaminant in the trees was estimated. The relationships between leaf and wood, pines and hardwood, location, and mass of the material in each of these classes were used to weight the total inventory estimate. The radionuclide with the largest inventory was $0.7 \mathrm{mCi}$ for ${ }^{90} \mathrm{Sr}$. The metallic contaminant with the largest inventory was $\mathrm{Mn}$ at $200 \mathrm{gm}$.
\end{abstract}

\section{INTRODUCTION}

Seepage basins are designed to contain aqueous waste so that the wastewater will flow into the soil at the bottom of the basin. Soils can be very effective filters for particulates suspended in water and generally are highly absorptive of cations in solution. Most soils have relatively low absorptive capacity for anionic solutes. Even though seepage basins have been very effective in removing the majority of radionuclides, such as ${ }^{137} \mathrm{Cs}$ and the transuranic nuclides, from wastewater, the use of seepage basins for treatment has been discontinued at Savannah River Site (SRS). This is, in part, because of the inability to remove some other radionuclides, such as ${ }^{90} \mathrm{Sr}$ and ${ }^{3} \mathrm{H}$. The measurements of radionuclide and metal contamination of vegetation growing adjacent to and in the Savannah River Laboratory (SRL, now the Savannah River Technology Center) Seepage Basins is part of the plan for closing this basin system. The total radionuclide and metallic element content of the vegetation will be used to choose disposal options for the vegetation when the basins are closed. 


\section{Description}

The SRL Basins and the sediments in the basins are described (Bransford et al. 1988). The following description of the SRL Basins is largely taken from this document.

The four Seepage Basins are located south of Road A-1 and west of Road D-1 in the northwestern section of SRS. The approximate coordinates of the southeast corner of Basin 1 are $33.345128{ }^{\circ} \mathrm{N}$ and $81.733505^{\circ} \mathrm{W}$.

The basins are rectangular in shape and were constructed by removing the earth from within the basins to form the surrounding dikes. The construction of Basins 1,2, and 3 principally involved excavation of natural soils and the construction of limited perimeter dikes. The construction of Basin 4 required substantial filling at the north end (adjacent to Tims Branch) to achieve both the basin bottom and the dike crest elevation.
Table 1. The Dimensions and Approximate Capacity of the SRL Seepage Basins.

\begin{tabular}{ccc} 
Basin & $\begin{array}{c}\text { Dimensions } \\
(\mathbf{L} \times \mathbf{W} \times \mathbf{m})\end{array}$ & Volume $\left(\mathrm{m}^{3}\right)$ \\
\hline 1 & $40 \times 19 \times 2.0$ & 1,520 \\
2 & $40 \times 40 \times 2.0$ & 3,200 \\
3 & $53 \times 38 \times 2.7$ & 5,440 \\
4 & $94 \times 46 \times 3.4$ & 14,700
\end{tabular}

Waste-water entered Basin 1 by a pipeline from SRL. The water overflowing Basin 1 entered Basin 2 and then sequentially into Basins 3 and 4 when the water flow was greater than the infiltration capacity of the preceding basins (see figure 1). Waste-water seldomly entered Basin 4 because the infiltration capacity of the first three basins equaled or exceeded the input volume. Water entering the sediment at the base of the water column appears to

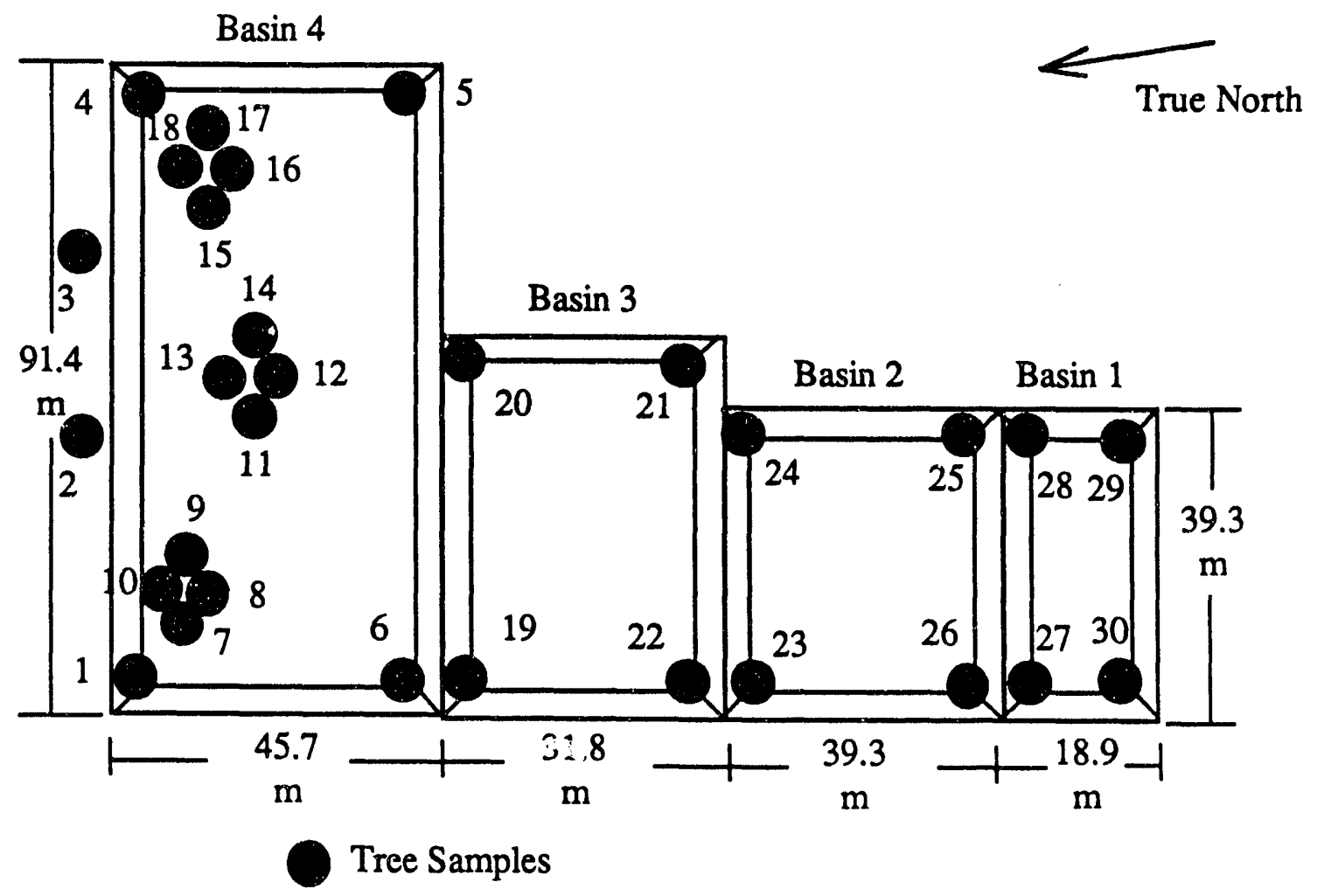

Figure 1. Layout and Sampling Scheme for Collection of Vegetation from the SRL Seepage Basins. 
have infiltrated downward, toward the ground water. There is no evidence that water from the basins reached Tims Branch, a small stream that is near down the hydrologic gradient from Basin 4.

Basins 1 and 2 have no vegetation growing on the basin botton. The bottom of these basins has generally remained covered with water, even after discharges to the basins stopped. The slopes of the basin dikes are densely covered with young trees. Most of the trees were less than ten years in age at the time of this sampling (June 1991). The majority of the trees are deciduous angiosperms (hardwoods), with a few scattered conifers (pines).

The bottom of Basin 3 also lacks any vegetation. At the time of this study, the basin bottom was intermittently covered with water. The vegetative cover on the slopes of the dikes surrounding Basin 3 contains less woody vegetation with a majority of the surface covered by grasses and herbaceous vegetation. The woody vegetation is largely hardwood trees with some scattered pines.

Basin 4 is the only basin that has trees growing on the bottom of the basin. Most of the basin is covered by a dense stand of young pines. A few hardwoods are also growing in the basin. The age of the trees was estimated to be less than ten years at the time of this study. The edge of the basin was characterized by a less dense stand of the same species. There is a small stand of older pine trees, estimated age 25 to 35 years, growing on the high dike separating the north side of Basin 4 from Tims Branch.

\section{History of Operation}

The first two basins were placed into operation in 1954. Basins 3 and 4 were added in 1958 and 1960 , respectively. SRL used the seepage basins to dispose of low-level radioactive liquid wastes. Pipes that tied into the low-level drains in the laboratories transferred the waste into one of four underground tanks. When one of the tanks accumulated approximately $20 \mathrm{~m}^{3}$ of waste, the contents were sampled. If the analysis of the wastewater indicated concentrations not exceeding $100 \mathrm{~d} /$ $\mathrm{m} / \mathrm{mL}$ alpha or $50 \mathrm{~d} / \mathrm{m} / \mathrm{mL}$ beta-gamma, the waste- water was discharged to the seepage basins. If concentrations exceeded these limits, the wastewater was sent to another facility.

Releases to the SRL Seepage Basins stopped after 1982. During the 28-year loading history, approximately $130,000 \mathrm{~m}^{3}$ of water were discharged to the basins. Table 2 lists the radioactive releases between 1958 and 1980. An estimate of the total discharge of other contaminants was made on the basis of the concentrations in the low-level waste stream sampled during October, 1982. The loadings of selected metals are listed in Table 3.

\section{Soil Concentrations \\ Description of Sampling Sites}

Shelby tube samplers bored five $20 \mathrm{ft}$. sample cores from the bottom of each basin, a total of twenty cores. The top $2 \mathrm{ft}$ of each Shelby sampler was cut into 3-inch segments which were removed from the tube segments in the field. Below the top $2 \mathrm{ft}$, 3-ft. intervals were used for analysis. A total of 280 sediment samples were collected.

Following collection, the samples were shipped to a contract laboratory (Envirodyne) for analysis. A description of the analytical techniques

Table 2. Radioactive Releases to the SRL Seepage Basins from 1958 to 1980 (Bransford et al. 1988).

\begin{tabular}{lc} 
Radionuclide & Released Activity (Ci) \\
\hline${ }^{3} \mathrm{H}$ & 105 \\
$89,90 \mathrm{Sr}$ & 0.4 \\
$137 \mathrm{Cs}$ & 4.7 \\
Natural U & 0.022 \\
$238 \mathrm{Pu}$ & 0.009 \\
$239 \mathrm{Pu}$ & 0.003 \\
${ }^{241} \mathrm{Am}$ & 0.001 \\
$242,244 \mathrm{Cm}$ & 0.001 \\
$103,106 \mathrm{Ru}$ & 1.4 \\
$60 \mathrm{Co}$ & 0.1 \\
$141,144 \mathrm{Ce}$ & 2.7 \\
Alpha (unidentified) & 4.2 \\
Beta-gamma & 10.6
\end{tabular}


Table 3. Estimated Releases of Selected Metals (Bransford et al. 1988).

\begin{tabular}{lr} 
Element & Release $(\mathbf{k g})$ \\
\hline Barium & 64 \\
Chromium & 1,220 \\
Mercury & 26 \\
Magnesium & 810 \\
Manganese & 438 \\
Nickel & 670 \\
Lead & 515 \\
Zinc & 219
\end{tabular}

can be found in Bransford et al. (1988)

\section{Differences between Basins}

Figure 2illustrates the average concentration of the seven radionuclides measured in the top two feet of the sediments, relative to the maximum value measured. The concentrations fall into three patterns. The concentration of ${ }^{137} \mathrm{Cs}, 238 \mathrm{Pu}$, and $239,240 \mathrm{Pu}$ increase from Basin 1 to a maximum in Basin 2 and decrease in Basin 3 and further to a minimum in Basin 4. ${ }^{90} \mathrm{Sr}$ concentrations peak in Basin 3.

$241 \mathrm{Am}$ and $242,244 \mathrm{Cm}$ show the pattern of a peak in concentration in Basins 2 but a'so show an increase in concentration between Basins 3 and 4. The variability in cores from the same basins is large enough that the increase between Basins 3 and 4 may be an artifact of the sampling procedure.

Similar analysis of the six elemental contaminants, $\mathrm{Ba}, \mathrm{Cr}, \mathrm{Hg}, \mathrm{Mg}, \mathrm{Mn}$, and $\mathrm{Ni}$ show similar patterns. All have peak concentrations in Basin 2. Ba, and $\mathrm{Cr}$, show an increase in concentration between Basins 3 and 4, while the other elements show a continued decrease. The levels of two contaminants that show up in vegetation, $\mathrm{Hg}$ and $\mathrm{Pb}$, are too low in the sediments to be able to

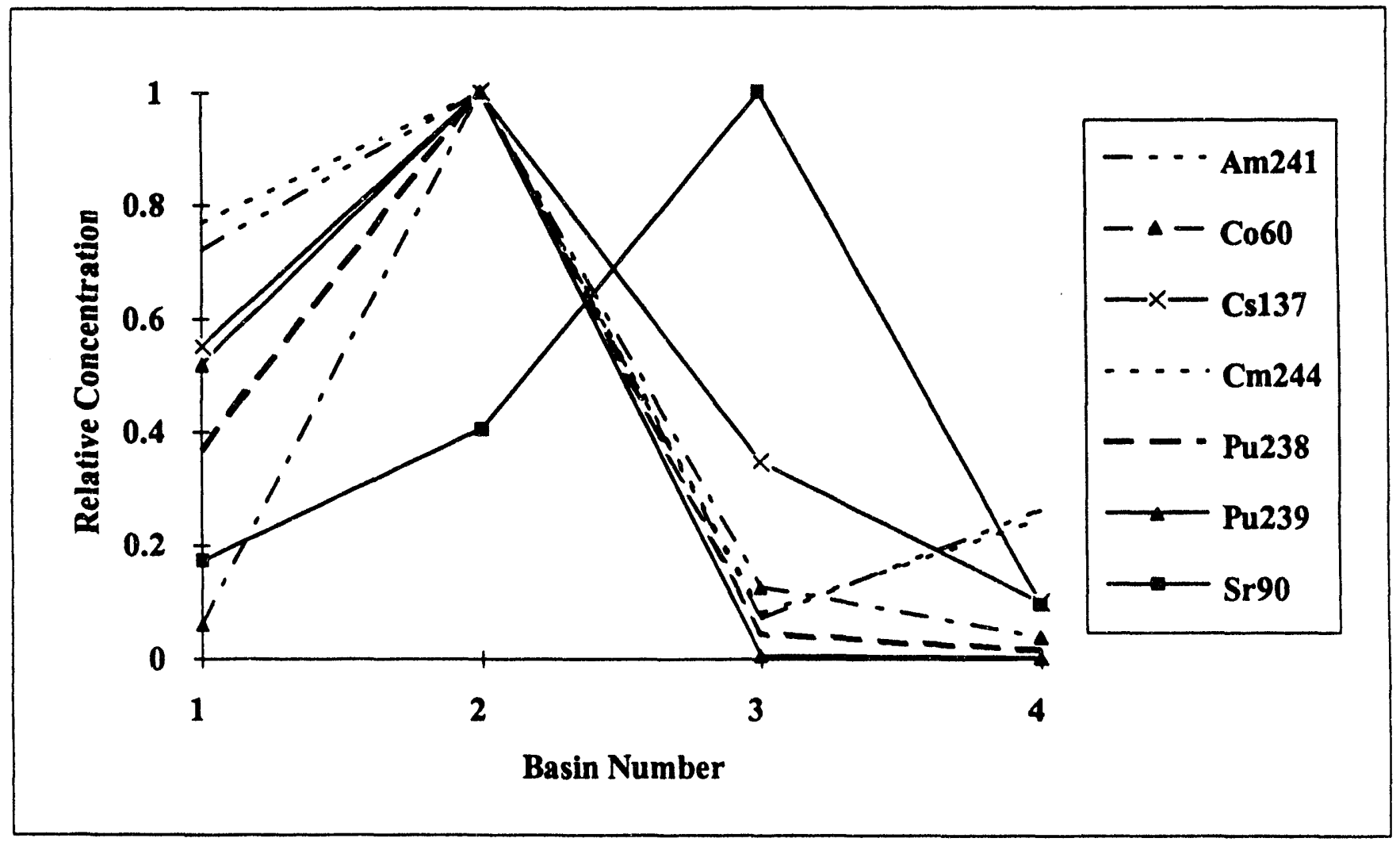

Figure 2. Distribution of Radionuclides among Basins. Waste-Water entered at Basin 1 and only rarely reached Basin 4. 
determine their spatial distribution among the Basins.

\section{Variation with Depth}

With a few exceptions, the concentration of all the contaminants measured in both the vegetation and the sediments show a marked decrease in concentration with distance from the surface. This is expected if these radionuclides and metallic elements are strongly absorbed by the sediments. In many cases, a straight line relationship is found between concentration and depth when the concentration of a radionuclide or a metal collected at a particular depth is plotted against depth in logarithmic coordinates. Figure 3 illustrates this for the average concentration of ${ }^{137} \mathrm{Cs}$ in the cores from Basin 4.

Figure 4 shows the slope of the straight lines for each radionuclide and metal for each basin. The slopes, an indication of the rate of change in

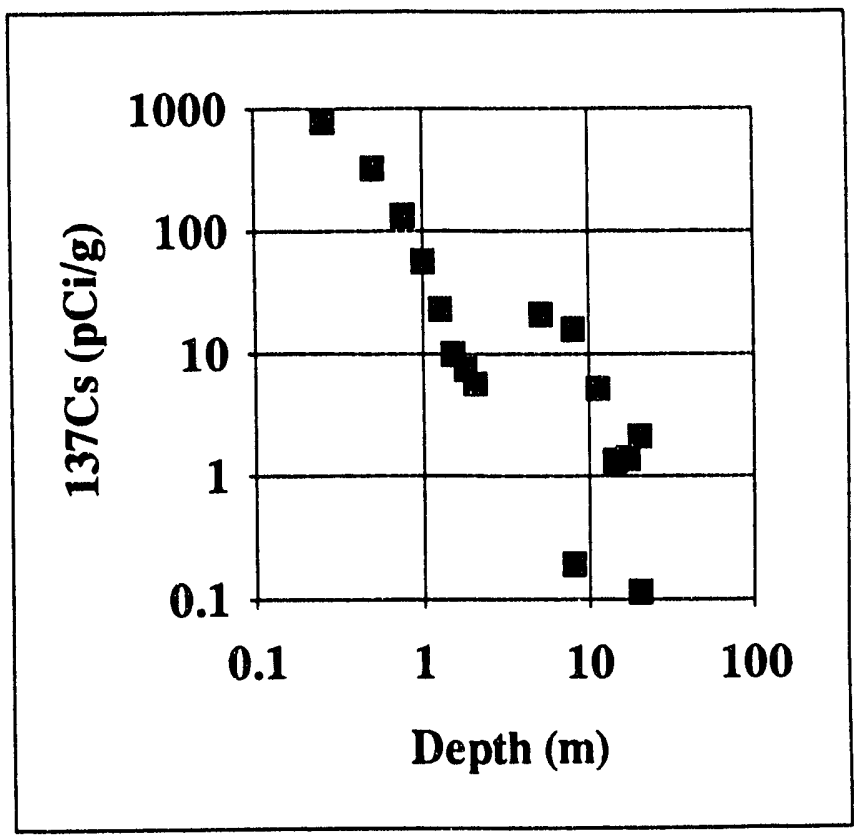

Figure 3. The Decrease in ${ }^{137} \mathrm{Cs}$ with Distance from the Surface.

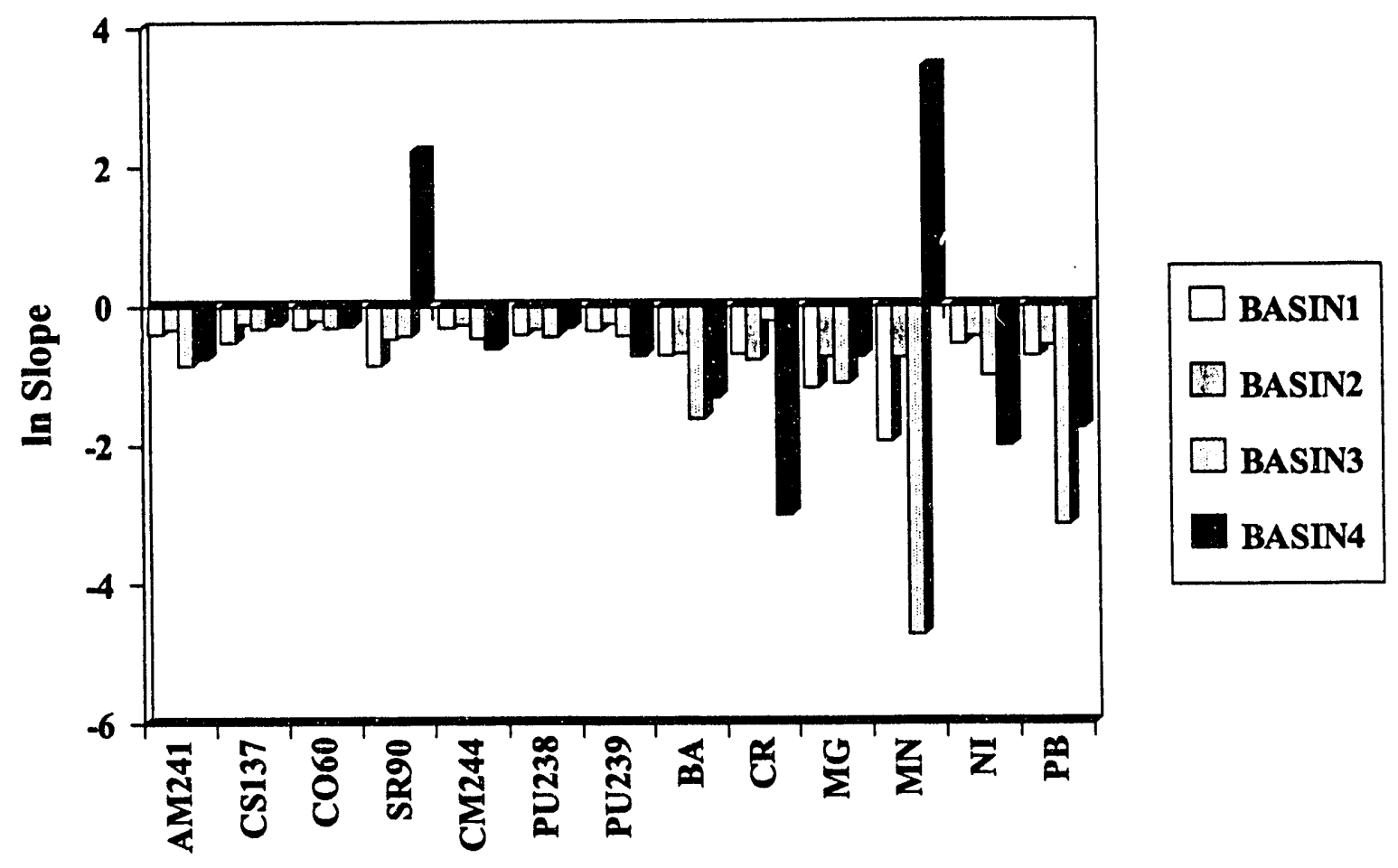

Figure 4. The Slope (Logarithmic) of Contaminant Concentration versus Distance from the Surface in Each Basin. 
concentration with depth, are very similar for most of the radionuclides. The slopes of this relationship for the metallic elements shows a greater variability between elements and between the same element in different basins. Only $90 \mathrm{Sr}$ and $\mathrm{Mn}$ in Basin 4 show a positive slope (increasing concentration with depth). No explanation is available to explain the reason for the positive slopes. The fact that Basin 4 only rarely received wastewater and it is the basin having vegetation growing on the bottom of the basin may partially explain this behavior.

\section{METHODS}

\section{Sample Collection}

One kilogram of leaves and one kilogram of branch wood were collected for analysis. Each sample consisted of material from a single tree placed in double polyethylene bags which were sealed before moving to the next sampling location.

Vegetation samples were taken from the edge of the basins at each of the four corners. The corners were selected because the they could be easily located if more sampling was needed later and because the trees closest to the edge of the basins were likely to show the highest concentrations. In addition to the 16 locations at the edge of each basin, 12 trees growing on the bottom of Basin 4 were sampled. Four trees were selected closest to the three soil sampling locations identified as 4-1, 4-3, and 4-5 in Bransford et al. (1988), Identified as sample location 7 through 9, 10 through 14, and 15 through 18 respectively in Figure 1. Two additional trees were sampled near the top of the dike on the north side of Basin 3. A total of 60 samples were collected, 30 leaf samples and 30 branch wood samples (see figure 1).

The samples were sealed in a DOT type 7A drum. The drum was shipped to Themo Analytical, Inc., Richmond, CA where the vegetation was analyzed for selected radionuclides and metallic elements.

\section{Analysis}

\section{Sample Preparation}

The total weight of the vegetation sarnple was taken. The sample was homogenized. A measured fraction was taken and dried. A dried weight was obtained to determine percent moisture. From this fraction an aliquot was taken and ashed for dissolution.

\section{Radionuclides}

The required radiological analyses were performed on aliquots of undried vegetation, dried vegetation, or dissolved vegetation depending on the volatility of the elements. A $500 \mathrm{~mL}$ sample of dried vegetation was prepared for gamma counting $\left({ }^{137} \mathrm{Cs},{ }^{60} \mathrm{Co}\right)$ and placed in a Marinelli beaker and weighed. The sample was counted for at least 400 minutes on a $\mathrm{Ge}(\mathrm{Li})$ high-resolution gamma spectrometer. The gamma spectrum was evaluated and quantified by a computer program. Positive peaks above background were calculated to desired units. The instruments were calibrated using multiple gamma standard solutions.

Ashed samples were leached with $\mathrm{HNO}_{3}$ and $\mathrm{H}_{2} \mathrm{O}_{2}$ solutions and filtered. The leached sample was then ashed and sequentially treated with HF/ $\mathrm{HNO}_{3}, \mathrm{H}_{3} \mathrm{BO}_{3}, \mathrm{HCL}$, and $\mathrm{HNO}_{3}$. The solution remaining after these treatments was added to the leachate. A sequential chemical separation of the dissolved vegetation was used to separate fractions for $\mathrm{Sr}, \mathrm{Pu}$, and $\mathrm{Am}-\mathrm{Cm}$ analysis. The tracers ${ }^{85} \mathrm{Sr}$, ${ }^{243} \mathrm{Am}$, and ${ }^{242} \mathrm{Pu}$ were used in the analyses. Plutonium is separated on an ion exchange column. The eluted $\mathrm{Pu}$ was electroplated onto a stainless steel disc for counting by alpha spectrometry.

The fraction passing through the $\mathrm{Pu}$ ion exchange column was back extracted and concentrated. The Am-Cm fraction was separated from the $\mathrm{Y}$ carrier on an anion exchange column. After further purification, the Am-Cm fractionwas electroplated on a stainless steel disc for counting by alpha spectrometry.

Each of the alpha-emitting actinides, which has been deposited on stainless steel discs, was 
counted for at least 1000 minutes on an alpha spectrometer. The spectrum was analyzed by a computer program that used the peak intensities and the yields calculated from the tracers to calculate the concentration of these nuclides.

Problems were encountered with the 241 Am and $242,244 \mathrm{Cm}$ analysis because of interference by other radioisotopes in the samples. The comparatively high levels of ${ }^{244} \mathrm{Cm}$ in some of the samples interfered with the ${ }^{241}$ Am spectra. This raised the minimum detectable level in three of the samples. The laboratory also found unusually high recoveries of the ${ }^{243} \mathrm{Am}$ tracer. It is suspected that the presence of $245 \mathrm{Cm}$ interfered with the ${ }^{243} \mathrm{Am}$ spectra. The samples showing the high recovery of the tracer were reanalyzed, without tracer, and the peak was corrected by comparison with the $244 \mathrm{Cm}$ peak.

Further decontamination of the $90 \mathrm{Y}$ from the $\mathrm{Am}-\mathrm{Cm}$ separation is done by coprecipitation of $\mathrm{Y}$. The precipitate is ashed to $\mathrm{Y}_{2} \mathrm{O}_{3}$ and mounted in a copper backed Mylar film sandwich on a Nylon planchet for beta counting. Each sample is counted up to 5 times to check the decay of $90 \mathrm{Y}$. This is used to calculate the amount of $90 \mathrm{Sr}$ at the time of collection.

\section{Metals}

The metal concentration in the vegetation samples, except $\mathrm{Hg}$, were determined by atomic absorption analysis using EPA Method's 7080, $7190,7450,7460,7520,7420$, and 7950, respectively for $\mathrm{Ba}, \mathrm{Cr}, \mathrm{Mg}, \mathrm{Mn}, \mathrm{Ni}, \mathrm{Pb}$, and $\mathrm{Zn}$. Mercury analysis was done by the cold vapor technique described in EPA method 7470 (EPA 1986).

\section{RESULTS}

The primary goal of this project was determining the total radionuclide and metallic element content of the vegetation. The best estimate of the total quantity of these materials requires a knowledge of the distribution of the materials. For instance, if there is a consistent difference in the concentration of a contaminant between the tree leaves and the wood, an estimate based only on the wood might be biased. Three factors were investigated to improve the accuracy of the final estimate of the total inventory of each contaminant:

1) the relationship between concentration in leaves and wood

2) the difference in concentration between pines and hardwoods, and

3) the location of the trees relative to the basins.

\section{Comparison of Leaves and Wood}

The concentration of each contaminant in the wood was plotted against the concentration in the leaves collected from the same branch. Figures 5 is an example of the relationship found for $90 \mathrm{Sr}$. A straight line was fit to this relationship by leastsquares regression. The slopes of the regression lines are an estimate of the concentration expected in leaf tissue given the concentration of wood tissue from the same branch. If the slope is 1.0 the concentrations would be expected to be identical.

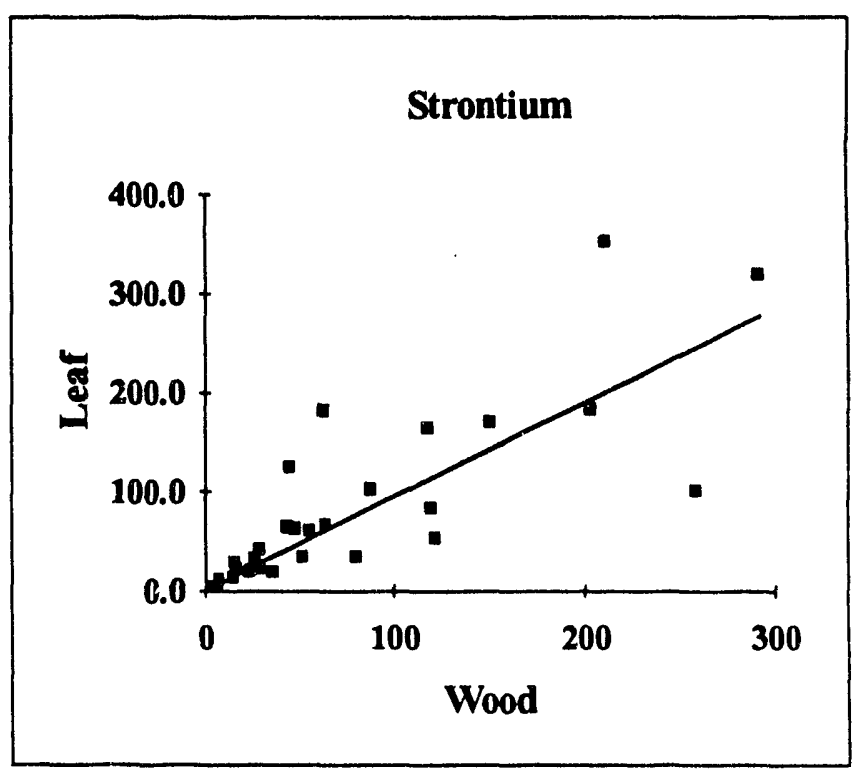

Figure 5. Relationship of Leaf to Wood Concentration for Strontium-90. 
Table 4 lists the slope for each of the analyzed contaminants. All of the slopes except ${ }^{23}, 8 \mathrm{Pu}$ and $\mathrm{Pb}$ are statistically significantly different from unity, suggesting that leaf concentrations of contaminants are different from wood concentrations. In the case of these two contaminants there is no choice but to pool the leaf and branch data when estimating the total contaminant concentration in the vegetation. However, even though the slopes calculated for $239,240 \mathrm{Pu}, 242,244 \mathrm{Cm}, 241 \mathrm{Am}$, $\mathrm{Cr}$, and $\mathrm{Ni}$ are significantly different from unity, the low regression coefficients, shown in column 3 , indicate that the slopes do not provide reliable predictions of leaf concentrations from wood concentrations. The relationships for ${ }^{90} \mathrm{Sr}, 60 \mathrm{Co}$, ${ }^{137} \mathrm{Cs}, \mathrm{Ba}, \mathrm{Mg}$, and $\mathrm{Mn}$ arc stronger and can be used to estimate different concentrations for the leaves and the wood. Even in the case of these contaminants it should be recognized that the slopes for $90 \mathrm{Sr}$ and $\mathrm{Ba}$ are so close to unity that there is no practical difference between leaf and wood concentrations.

Table 4. Ratio of Concentration in Leaves to Concentration in Wood.

\begin{tabular}{llc} 
Contaminant & Slope & R-square \\
\hline${ }_{90 \mathrm{Sr}}$ & $1.05^{*}$ & 0.81 \\
$60 \mathrm{Co}$ & $3.21^{*}$ & 0.91 \\
${ }^{137 \mathrm{Cs}}$ & $2.72^{*}$ & 0.87 \\
$238 \mathrm{Pu}$ & 0.39 & 0.05 \\
$239,240 \mathrm{Pu}$ & $1.06^{*}$ & 0.29 \\
$242,244 \mathrm{Cm}$ & $0.63^{*}$ & 0.49 \\
$241 \mathrm{Am}$ & $1.63^{*}$ & 0.62 \\
$\mathrm{Ba}$ & $1.09^{*}$ & 0.84 \\
$\mathrm{Cr}$ & $1.03^{*}$ & 0.35 \\
$\mathrm{Hg}$ & $1.00^{*}$ & 0.77 \\
$\mathrm{Mg}$ & $4.11^{*}$ & 0.77 \\
$\mathrm{Mn}$ & $6.18^{*}$ & 0.87 \\
$\mathrm{Ni}$ & $2.55^{*}$ & 0.57 \\
$\mathrm{~Pb}$ & 0.13 & 0.19
\end{tabular}

* Slope significant at the 0.99 confidence level.

\section{Comparison of Pines and Hardwoods}

Preliminary inspection of the contaminant concentrations suggested that the concentrations of some contaminants were higher in the hardwood trees than in the pines (Table 5). Most of the trees on the edges of Basins 1, 2, and 3 are hardwoods. Only in and around Basin 4 were there enough trees of each type to test the hypothesis that the mean concentrations were different.

Ratios of the mean concentration in hardwoods to the mean concentration in pines were calculated for each contaminant. Then the hypothesis of different mean values was tested by applying a Student t-test. Table 5 shows the ratios and the probability that the mean values are the same. The t-test suggests that the means are different for ${ }^{137} \mathrm{Cs}, \mathrm{Ba}, \mathrm{Mg}$, and $\mathrm{Mn}$. The differences for ${ }^{90} \mathrm{Sr}$, $\mathrm{Hg}, \mathrm{Pb}$ and perhaps ${ }^{\circ} \mathrm{Co}$ are marginal, while all other differences are within the range expected by random variation.

There are actually two sources of variation in the data from Basin 4. Most of the pines sampled are growing on the bottom of the basin while most of the hardwoods are on the edge of the basin. One would expect the pines to have higher concentra-

\section{Table 5. Ratio of Concentrations in Hard- wood/Pine in Basin 4.}

\begin{tabular}{crc} 
Contaminant & Ratio & P(T<=t) one-tail \\
\hline${ }_{90} \mathrm{Sr}$ & 2.77 & 0.071 \\
${ }^{60} \mathrm{Co}$ & 3.39 & 0.103 \\
${ }_{137} \mathrm{Cs}$ & 0.36 & 0.038 \\
$238 \mathrm{Pu}$ & 3.79 & 0.411 \\
$239,240 \mathrm{Pu}$ & 3.41 & 0.416 \\
$242,244 \mathrm{Cm}$ & 2.24 & 0.365 \\
$241 \mathrm{Am}$ & 3.64 & 0.341 \\
$\mathrm{Ba}$ & 13.89 & 0.002 \\
$\mathrm{Hg}$ & 0.70 & 0.055 \\
$\mathrm{Mg}$ & 3.06 & 0.005 \\
$\mathrm{Mn}$ & 3.44 & 0.012 \\
$\mathrm{Ni}$ & 1.46 & 0.690 \\
$\mathrm{~Pb}$ & 0.59 & 0.064
\end{tabular}


tions because they are rooted in sediments with higher concentrations of contaminants. Therefore, if the pine trees have higher concentrations than the hardwoods of a particular contaminant, this could be caused by either the pine trees being rooted in soil with a higher concentration of the contaminant or by the pine trees being more efficient in removing the contaminant from the soil or both. However, if hardwoods have higher concentrations of the contaminant and, on the average, are growing in sediment with a lower concentration of the contaminant, then the increased uptake is likely to have been caused by an actual increase in the efficiency of the hardwoods in removing this contaminant from the sediment. Therefore, the lower concentration of ${ }^{137} \mathrm{Cs}$ in pines (ratio less than 1) may have been caused by either sediment or vegetation conditions while the higher concentraion of ${ }^{90} \mathrm{Sr}, \mathrm{Ba}, \mathrm{Mn}$, and $\mathrm{Mg}$ are probably caused by vegetative processes.

\section{Relationship of Location to Concentration}

The effect of location is important only at Basin 4 which is the only basin with trees growing on its bottom. At Basins 1 and 2, most of the trees are growing on the slope of the dike surrounding the basin and are not very far from the basin edge. Basin 3 has comparatively few trees, and most are on the edge of the basin. Therefore the effect of location was evaluate for only Basin 4. Because of the difference in concentration between different species types, noted in the previous section, only hardwood trees were used in this analysis. The concentration of contaminants were not measured in pines at all the other locations. Figures 6 and 7 illustrate the effect of location for the radionuclides and metallic elements, respectively.

With the exception of $90 \mathrm{Sr}$, there is a large decrease in concentration of the radionuclides as the location of the tree is further from the basin. The relatively high concentrations of $90 \mathrm{Sr}$ in the trees growing on the basin edge and even the trees higher up on the dike, may be related to the relatively high mobility of ${ }^{90} \mathrm{Sr}$ in soils.

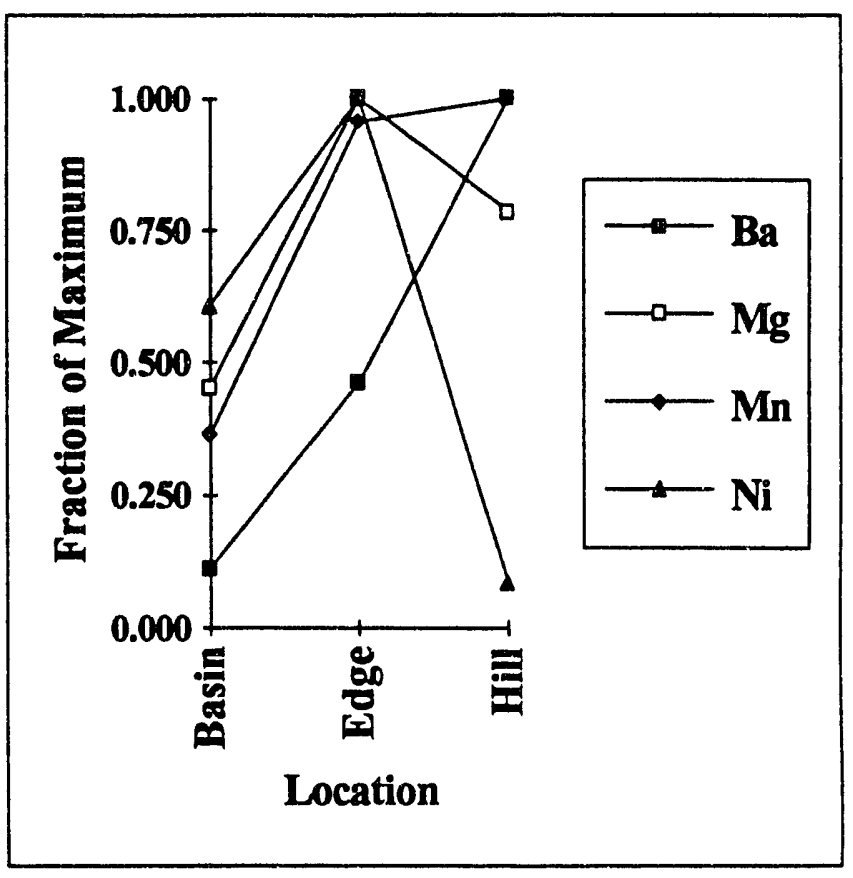

Figure 7. The Effect of Location on Average Metallic Contaminant Concentratious in Basin 4.

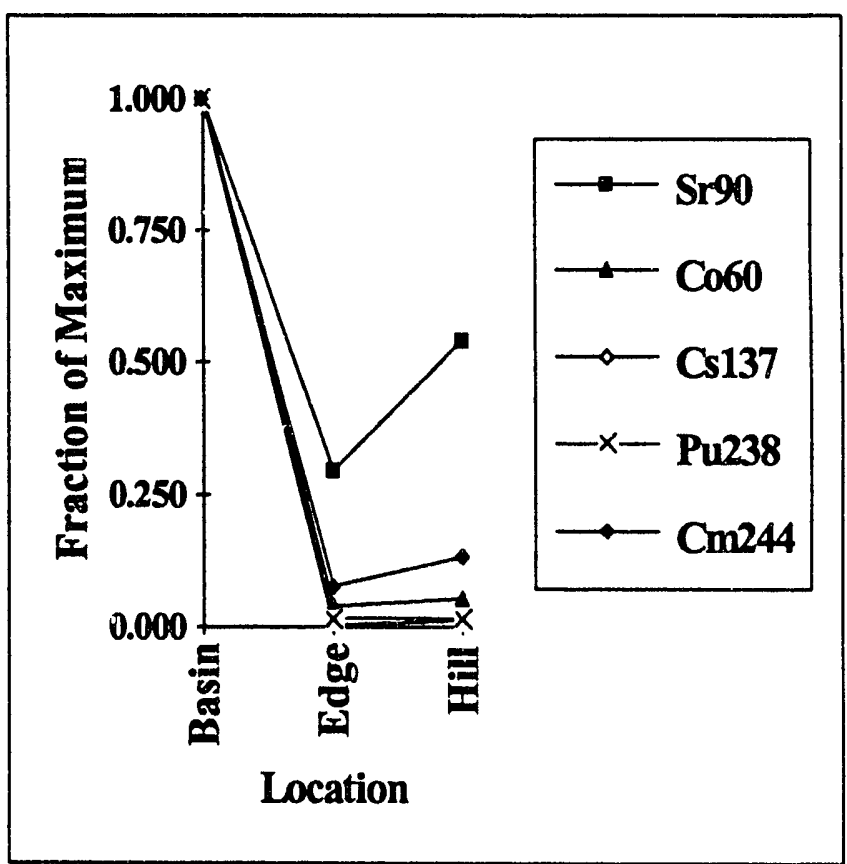

Figure 6. The Effect of Location on Average Radionulcide Contaminant Concentrations in Basin 4. 
The relationship of concentration in the vegetation and the location of the trees is very different for the four metallic elements $(\mathrm{Ba}, \mathrm{Mg}, \mathrm{Mn}$, and $\mathrm{Ni})$. The concentration in the vegetation was actually higher for trees growing on the edge of the basin than on the bottom. This is difficult to explain by any known process. Since Basin 4 received only limited amounts of wastewater, the concentrations of these naturally occurring elements may be higher in the soil used for the dikes than the soil in the bottoms of the basin.

\section{Vegetation/Soil Concentration Ratios}

Concentration ratios are used to estimate the concentration of contaminant in one component of the environment given the concentration in another component that is the primary source of the contaminant to the former component. Vegetationsoil concentration ratios are used when the soil is the primary source of the contaminant of interest. Vegetation-soil uptake ratios vary greatly because of the complex relationship between environmental factors that effect the uptake of materials from soils. One important factor under field conditions is the depth of vegetation rooting. The ratios presented here were calculated on the basis of an average concentration over the top $1 \mathrm{ft}$ of sediment. The same calculations for an average over $2 \mathrm{ft}$ of sediment will give ratios that are approximate twice the ratio for contaminants retained in the upper few inches of the soil, such as ${ }^{137} \mathrm{Cs}$, but give little difference for contaminants that are more uniformly distributed with depth, such as $90 \mathrm{Sr}$. For this reason concentration ratios developed under similar condition of soil type, water regime, soil contaminant distribution, and vegetation are used whenever possible.

Normally, this approach is used when vegetation is grown in soil with a well-characterized radionuclide concentration. Concentration ratios will also be calculated for vegetation growing on the edge of the SRL Basins. As described in the previous section, the effects of location, species type and soil will influence the vegetation concen- tration relative to the concentration in the sediment on the bottom of the basin. While not an ideal situation, the concentration ratios derived may still be the best way of estimating radionuclide and, perhaps, metallic element concentrations around similar seepage basins.

The results of the concentration ratios presented in Table 6 and Figures 8 and 9, are give as geometric means with logarithmic-transfromed one standard deviation error bars. This was done because the frequency distribution of the data was limited at the lower end of the range by minimum values that are near zero. This leads to skewed frequency distributions that resembles a log-normal distribution.

\section{Vegetation on the Bottom of Basin Four}

Table 6 and Figure 8 illustrate the concentration ratios calculated for the pine trees growing on the bottom of Basin 4. The uptake ratios are calculated for the leaves. Ratios for wood can be calculated by dividing the leaf ratios by the factors developed in the previous section. The concentration ratios are compared to ratios and ranges of ratios from several other sources; few results are available for trees. The quoted means and ranges are, for the most part, from the vegetative parts of food crops or forage. The occasional tree values fall in this range.

With the exception of $\mathrm{Mg}, \mathrm{Cr}$, and $\mathrm{Ba}$, which are significantly higher, the concentration ratios fall within the range of previously determined ratios. In the case of $\mathrm{Mg}, \mathrm{Cr}$, and $\mathrm{Ba}$ the range of concentration ratios were only available in Baes et al. (1984), which generally indicated a lower range of ratios than Coughtrey et al. (1985) or Till and Meyer (1983).

However, even for contaminants where the concentration ratio falls within the range of previous measurements, the mean concentration ratio at the SRL Basins is higher than the mean literature values for a number of the contaminants. The most likely explanation is that many of the soils used in previous studies are fertilized for crop production. 


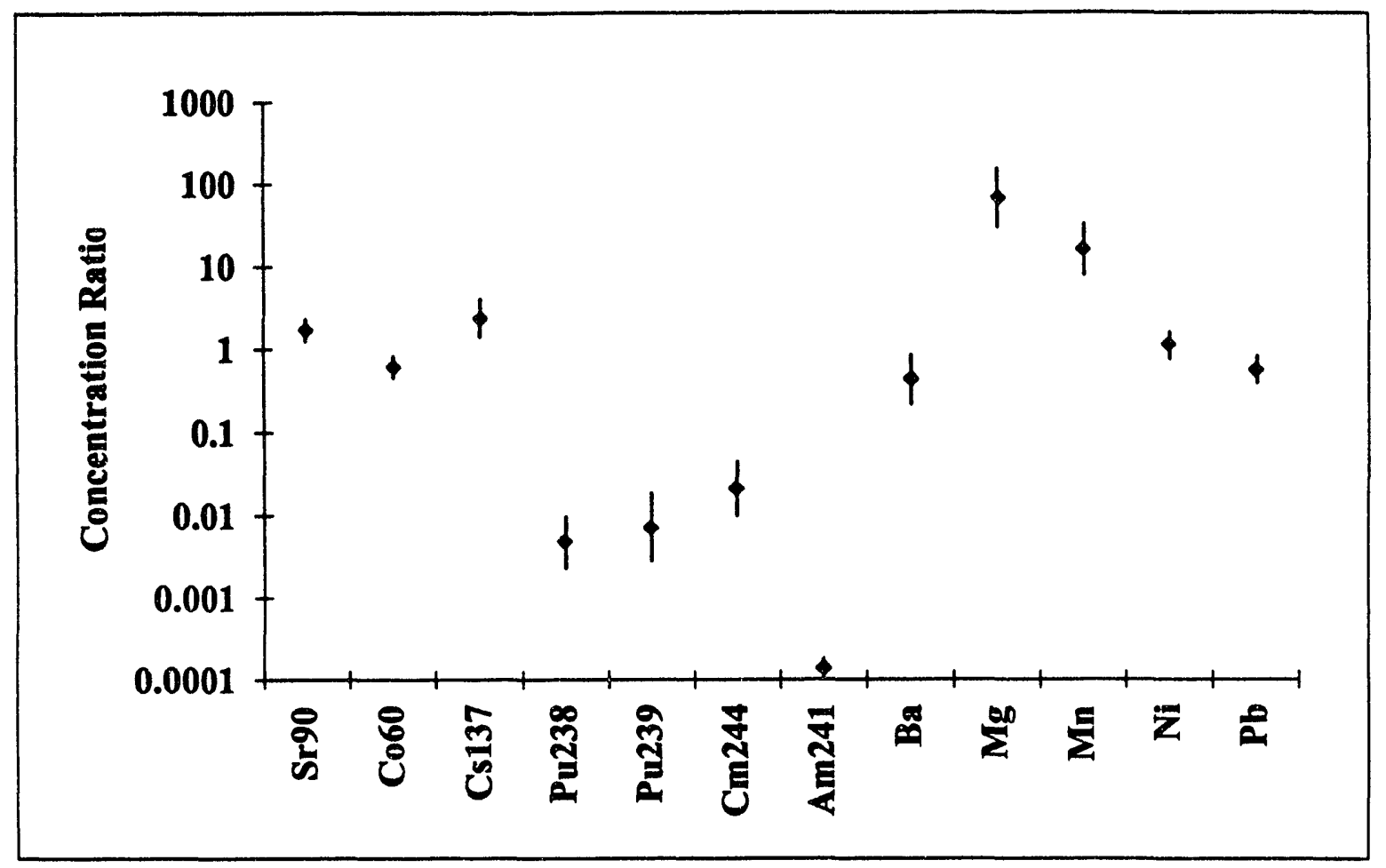

Figure 8. Geometric Mean Vegetation/Soil Concentration Ratios for Trees growing in the Sediment of Basin 4.

Table 6. Concentration Ratios Measured at SRL Seepage Basins and a Literature Survey.

\begin{tabular}{|c|c|c|c|c|}
\hline \multirow[b]{2}{*}{ Nuclide/Element } & \multicolumn{2}{|c|}{ SRL Basins } & \multicolumn{2}{|c|}{ Literature } \\
\hline & $\overline{\operatorname{Basin} 4}$ & Edge & Mean & Bange \\
\hline $90 \mathrm{Sr}_{\mathrm{r}}$ & 1.69 & 0.88 & $2.93^{(2)}$ & $(0.1-20)^{(2)}$ \\
\hline${ }^{60} \mathrm{Co}$ & 0.61 & 0.018 & $0.06(1)$ & $(0.01-1)^{(3)}$ \\
\hline${ }^{137} \mathrm{Cs}$ & 2.37 & 0.0052 & $0.26(2)$ & $(0.1-10)^{(3)}$ \\
\hline $238 \mathrm{Pu}$ & 0.0047 & 0.00015 & $0.00045^{(1)}$ & $(0.006-0.1)^{(2)}$ \\
\hline $239,240 \mathrm{Pu}$ & 0.0073 & 0.00012 & $0.00045^{(1)}$ & $(0.006-0.1)^{(2)}$ \\
\hline $242,244 \mathrm{Cm}$ & 0.021 & 0.0052 & $0.00085^{(1)}$ & $\left(10^{-6}-1.7\right)^{(2)}$ \\
\hline${ }^{241} \mathrm{Am}$ & 0.00014 & 0.00025 & $0.0055^{(1)}$ & $\left(10^{-4}-10^{-1}\right)^{(2)}$ \\
\hline $\mathrm{Ba}$ & 0.43 & 5.0 & $0.005^{(1)}$ & $(0.056-0.16)^{(1)}$ \\
\hline $\mathrm{Cr}$ & ND & 0.049 & $0.02(3)$ & $\left(10^{-3}-0.0145\right)^{(1)}$ \\
\hline $\mathrm{Mg}$ & 67. & 60. & $1.0(1)$ & $(0.2-4.0)^{(1)}$ \\
\hline $\mathrm{Mn}$ & 16 & 17 & $1.48^{(2)}$ & $(1-100)^{(2)}$ \\
\hline $\mathrm{Ni}$ & 1.12 & 0.43 & $0.06(1)$ & $(0.1-10)^{(2)}$ \\
\hline $\mathrm{Pb}$ & 0.58 & 0.15 & $0.10^{(1)}$ & $(0.013-0.9)^{(1)}$ \\
\hline
\end{tabular}

Sources: (1) Baes et al. 1984, (2) Coughtrey et al. 1985, and (3) Till and Meyer 1983. $\mathrm{ND}$, no data above detection limit for either soil or vegetation. 


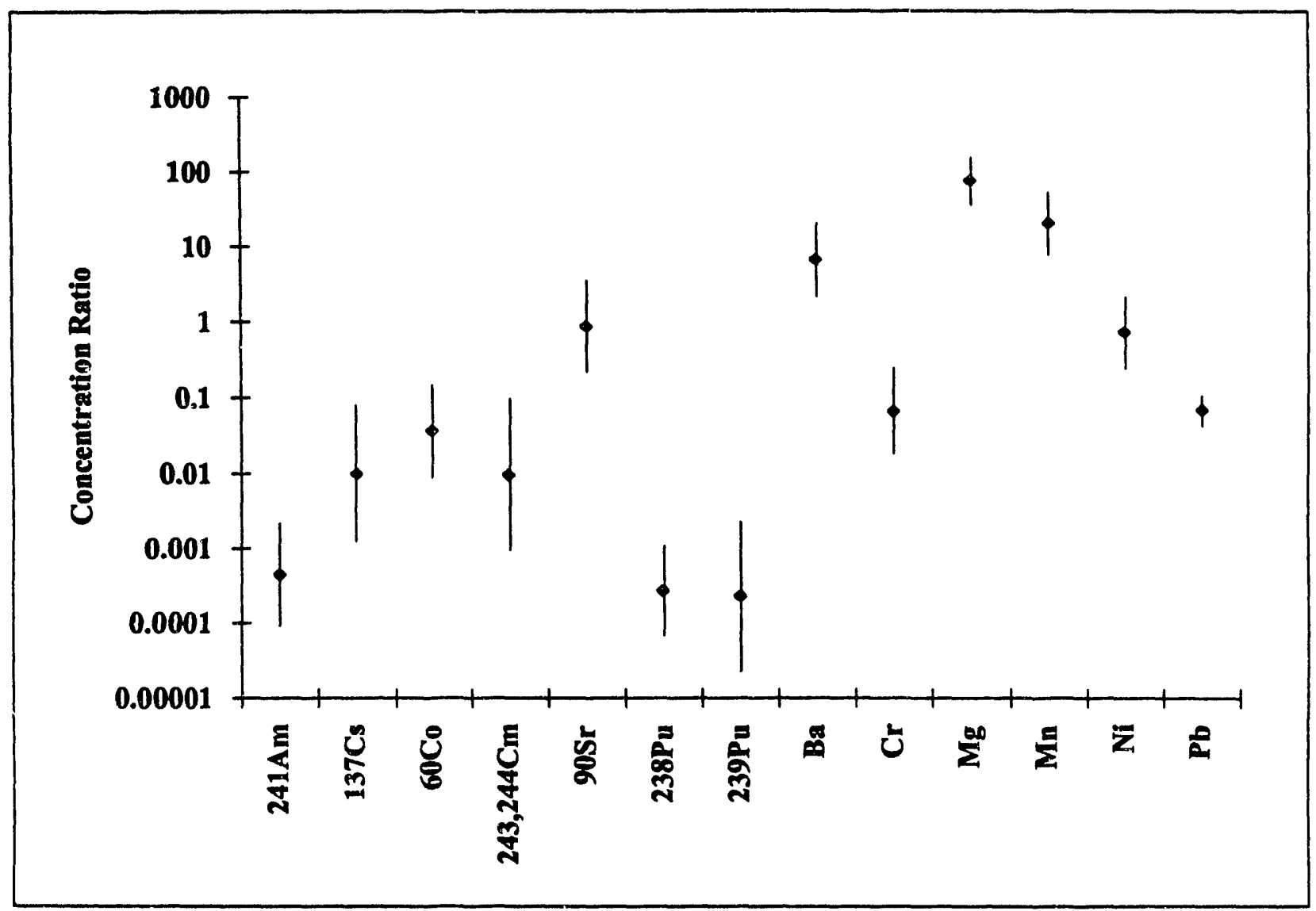

Figure 9. Geometric Mean Vegetation/Soil Concentration Ratios for Trees growing on the Edge of All the Basins.

Fertilization should increase the concentration of $\mathrm{Ca}$ and $\mathrm{K}$, which are known to compete with $\mathrm{Sr}$ and Cs uptake respectively. The increased uptake of Cs in plants grown in low $\mathrm{K}$ soil is particularly pronounced on sandy soils, such as those found at SRS. Under these conditions the upper end of the uptake range has been found in the literature reviewed.

\section{Vegetation on the Edge of the Basins}

Table 6 and Figure 9 show the geometric mean concentration ratios calculated for the radionuclides and metallic elements measured in both trees and soil. The concentration factors are for leaves. The concentration ratios for wood can be found from the ratios developed in the section dealing with leaf-wood differences. The variability in concentration ratios, as illustrated by the one standard deviation (logarithmic transform) error bars in Figure 9, as expected, is large. However, it

is possible to use the results to provide an upper bound to the expected concentrations under similar conditions.

The average concentration ratio of the trees located at the edge the basins, show the same relationship to the concentration ratios for the trees in the bottom of basin 4 as the relationship to concentration with location at Basin 4. ${ }^{90} \mathrm{Sr}, \mathrm{Ba}$, $\mathrm{Mg}$, and $\mathrm{Mn}$ have high concentration ratios consistent with the relatively high concentrations of these contaminants in vegetation at the edge of the basin. These relatively high concentrations could be explained by either high mobility or high transport of these materials through roots extending under the basin. Conversely, contaminants such as ${ }^{137} \mathrm{Cs}$, $\mathrm{Pu}$ isotopes, and $241 \mathrm{Am}$ which appear to be less mobile have lower concentration ratios for the trees growing on the edge of the basins than for trees growing in the bottom of the basin. 
Estimation of Total Radionuclides and Metallic Elements in the Vegetation

Table 7 shows the quantity of each radionuclide and element in each basin. The volume of each component was estimated on the basis of a vegetation survey of the seepage basins. All trees were tallied by height and diameter (at the soil line for small trees and at breast height for larger trees). Stem wood volume was estimate from Monk (1966) for smaller trees and from Wahlenberg (1960) for larger trees. Wood density was taken from Koch (1972). Based on data from these same sources, $20 \%$ was added for branch wood and $10 \%$ of the total was used to estimate the leaf mass. The $10 \%$ used for the leaf mass will under estimate the mass for small trees and over estimate it in the larger trees; however, the value is a reasonable mean for trees of the size growing in and adjacent to the basins.

The concentrations used in estimating the total inventory in any one category is the average of trees in that category, rather than the regression slope estimates extrapolated to each category. The greatest influence on the total inventories of each contaminant is the amount of tree mass growing in or adjacent to the basin.

Table 7. Total Contaminants in SRL Seepage Basin Trees.

\begin{tabular}{|c|c|c|c|c|c|}
\hline \multirow[b]{2}{*}{$\underline{\mathbf{m C i}}$} & \multicolumn{4}{|c|}{ Basin Number } & \multirow[b]{2}{*}{ Total } \\
\hline & 1 & 2 & 3 & 4 & \\
\hline$\overline{\text { Sr90 }}$ & $8.64 \bar{E}-02$ & $5.31 \mathrm{E}-02$ & $6.61 \bar{E}-02$ & $4.9 \overline{1} \mathrm{E}-01$ & $6.96 \mathrm{E}-01$ \\
\hline Co60 & $2.94 \mathrm{E}-05$ & $3.16 \mathrm{E}-05$ & 4.99E-04 & $4.29 \mathrm{E}-04$ & $9.89 \mathrm{E}-04$ \\
\hline Cs 137 & $1.51 \mathrm{E}-03$ & $1.86 \mathrm{E}-03$ & $1.40 \mathrm{E}-03$ & 5.65E-02 & $6.13 \mathrm{E}-02$ \\
\hline $\mathrm{Pu} 238$ & 2.44E-07 & $1.60 \mathrm{E}-07$ & 3.87E-08 & $1.12 \mathrm{E}-06$ & $1.57 \mathrm{E}-06$ \\
\hline $\mathrm{Pu} 239$ & $7.56 \mathrm{E}-07$ & $3.10 \mathrm{E}-07$ & $7.44 \mathrm{E}-08$ & 3.17E-06 & 4.31E-06 \\
\hline $\mathrm{Cm} 244$ & $1.14 \mathrm{E}-04$ & $5.04 \mathrm{E}-04$ & $1.35 \mathrm{E}-04$ & $4.35 \mathrm{E}-03$ & $5.10 \mathrm{E}-03$ \\
\hline Am241 & $1.10 \mathrm{E}-06$ & $6.34 \mathrm{E}-07$ & $3.99 \mathrm{E}-07$ & $2.20 \mathrm{E}-05$ & $2.41 \mathrm{E}-05$ \\
\hline \multicolumn{6}{|l|}{ gm } \\
\hline$\overline{\mathrm{Ba}}$ & $4.86 \mathrm{E}+01$ & $5.09 \mathrm{E}+01$ & $2.66 \mathrm{E}+01$ & $5.50 \mathrm{E}+02$ & $6.76 \mathrm{E}+02$ \\
\hline $\mathrm{Cr}$ & $2.05 E-01$ & $3.50 \mathrm{E}-01$ & $1.09 \mathrm{E}-01$ & $4.33 E+00$ & $5.00 \mathrm{E}+00$ \\
\hline $\mathrm{Hg}$ & $1.51 \mathrm{E}-02$ & $1.96 \mathrm{E}-02$ & $3.91 \mathrm{E}-03$ & $3.24 \mathrm{E}-01$ & $3.63 \mathrm{E}-01$ \\
\hline $\mathrm{Mg}$ & $7.09 \mathrm{E}+02$ & $5.04 E+02$ & $3.16 \mathrm{E}+02$ & $5.59 \mathrm{E}+03$ & $7.12 E+03$ \\
\hline $\mathrm{Mn}$ & $1.79 E+02$ & $2.34 \mathrm{E}+02$ & $4.63 \mathrm{E}+01$ & $1.59 E+03$ & $2.05 E+03$ \\
\hline $\mathrm{Ni}$ & $2.99 E+00$ & $2.48 \mathrm{E}+00$ & 8.83E-01 & $2.80 \mathrm{E}+01$ & $3.44 \mathrm{E}+01$ \\
\hline $\mathrm{Pb}$ & $6.60 \mathrm{E}-01$ & $5.00 \mathrm{E}-01$ & $3.84 \mathrm{E}-01$ & $6.59 E+01$ & $6.75 E+01$ \\
\hline
\end{tabular}




\section{REFERENCES}

Baes, C.G., R.D. Sharp, A.L. Sjoreen, and R.W. Shor. 1984. A Review and Analysis of Parameters for Assessing Transport of Environmentally Released Radionuclides through Agriculture. ORNL5786, Oak Ridge National Laboratory, Oak Ridge, Tenn. 150 pp.

Bransford, J.L., H.W. Bledsoe, R.V. Simmons. 1988. Technical Data Summary, Chemical Characterization of sediments and Groundwater at the Savannah River Laboratory Seepage Basins. DPSTD-84-110, E.I. du Pont de Nemours, Inc., Savannah River Laboratory, Aiken, S.C.

Coughtrey, P.J., D. Jackson, M.C. Thorne. 1985. Radionuclide Distribution and Transport in Terrestrial and Aquatic Ecosystems. A.A. Balkema Publ., Boston, 6 Volumes.

EPA. 1986. Test Methods for Evaluating Solid Wastes, Vol. 1A, USEPA, Superintendent of Documents, Washington, D.C.

Koch, P. 1972. Utilization of Southern Pines. Agriculture Handbook No. 420, Vol I, U.S.D.A., Superintendent of Documents, Washington, D.C., pp 238, 582.

Monk, C.D. 1966. Root-shoot dry weights in loblolly pine. Bot. Gaz. 127: 246-248.

Till, J.E. and H.R. Meyer 1983. Radiological Assessment, NUREG/CR-3332, Superintendent of Documents, U.S. Government Printing Office, Washington, D.C.

Wahlenberg, W.G. 1960. Loblolly Pine. The School of Forestry, Duke University, Durham, N.C., p 270.

U.S. Nuclear Regulatory Commission. 1977. Regulatory Guide 1.109, Calculation of Annual Doses to Man from Routine Releases of Reactor Effluents ofor the Purpose ofEvaluating Compliance with 10 CFR Part 50 Superintendent of Documents, U.S ${ }_{1} 14$ Government Printing Office, Washington, D.C. 
APPENDIX

Concentration of Radionuclides and Metal in Trees 
$n 00000000000$

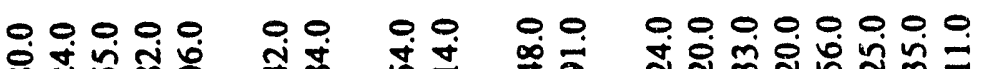
ñ

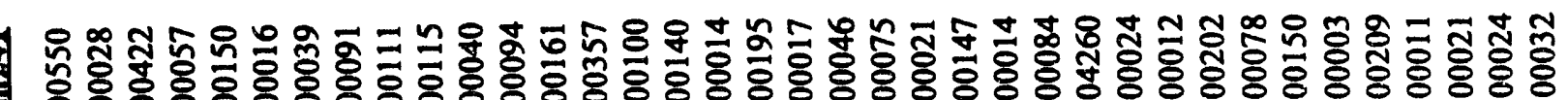

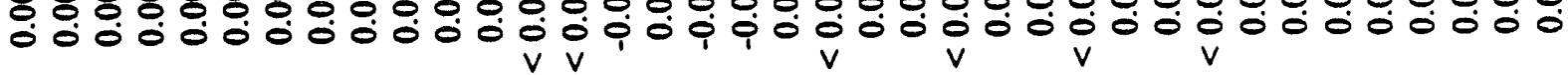
r.

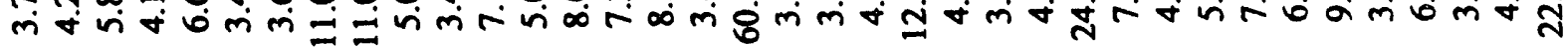

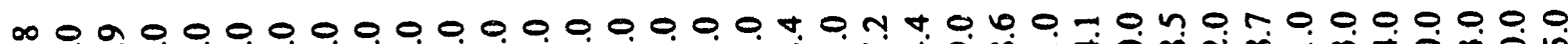
mi

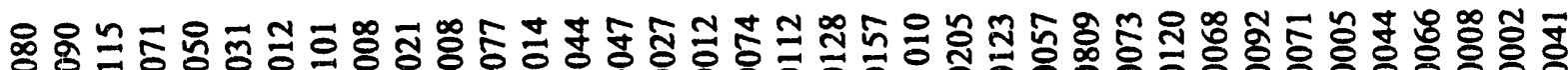

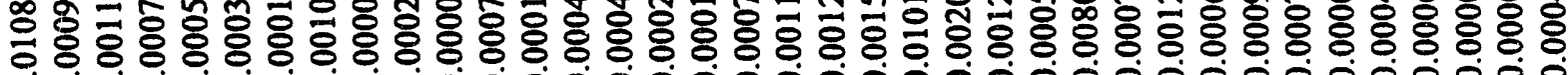

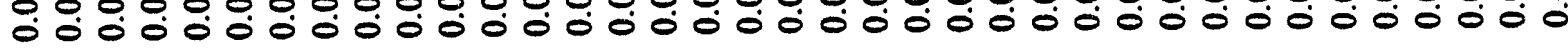

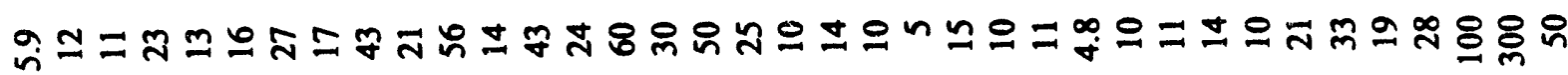

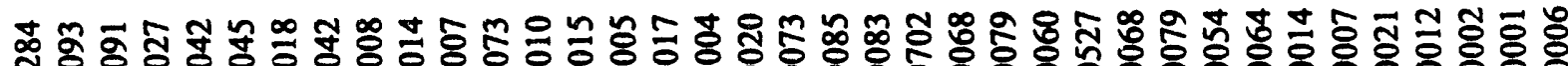

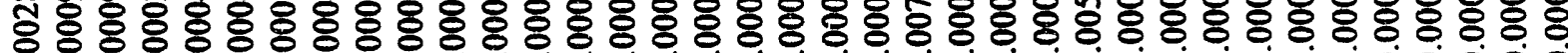
○ 0 O

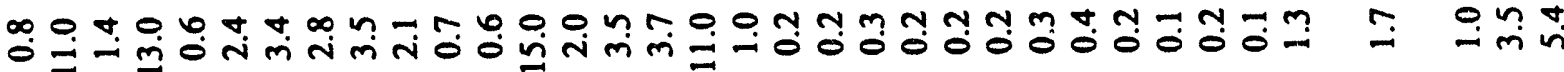

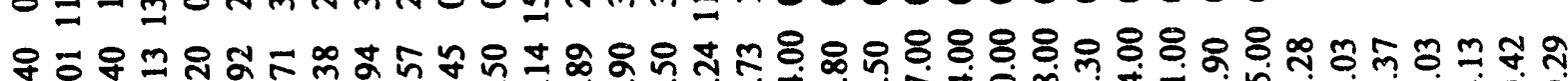
ذ̇o

$$
\text { 잉 }
$$

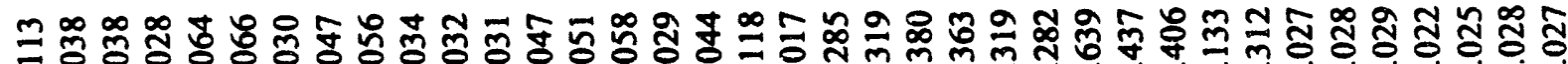

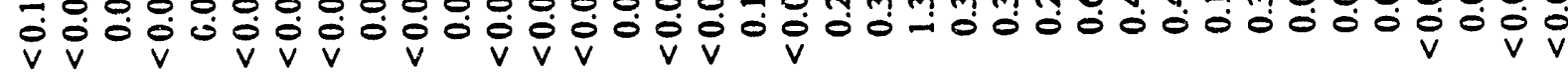

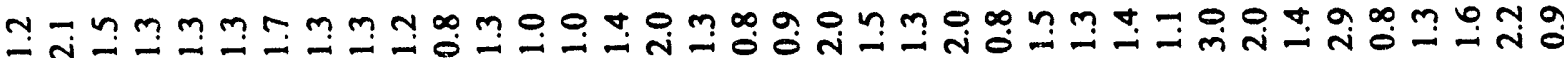

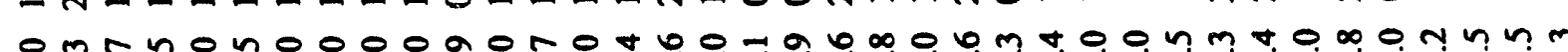

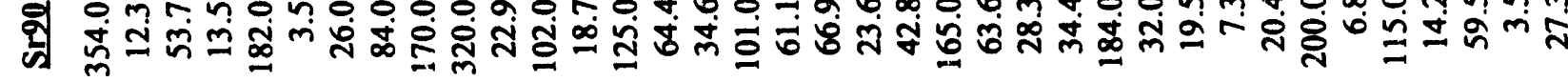

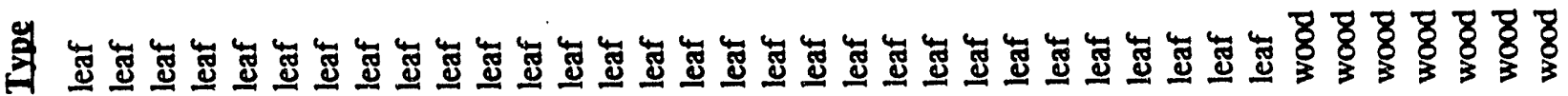

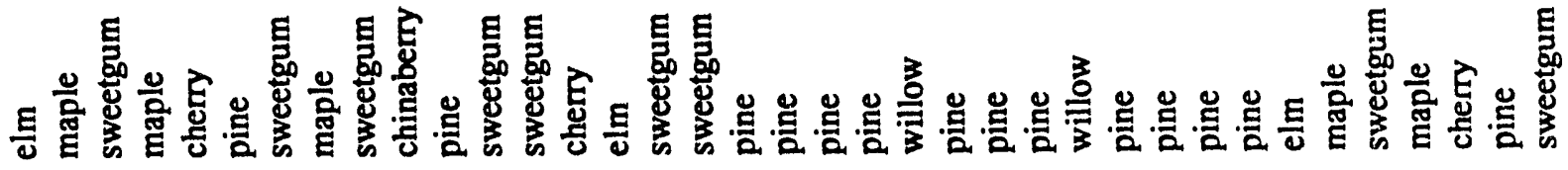

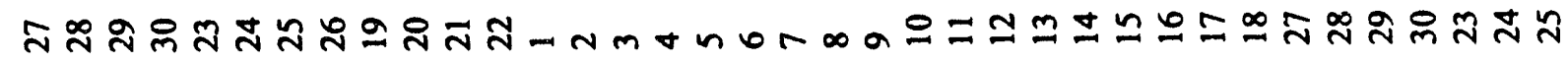




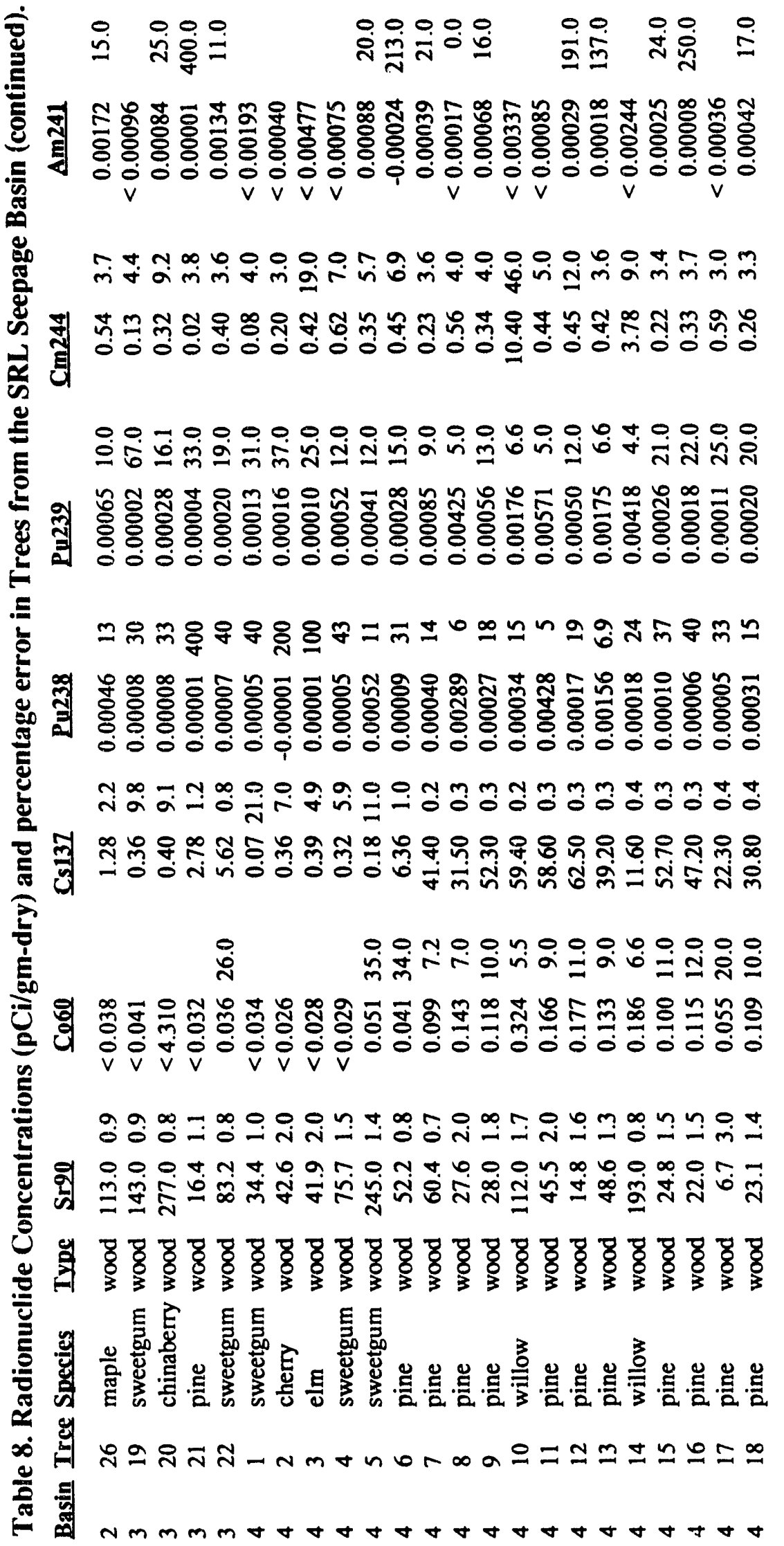


Aี

च 웅

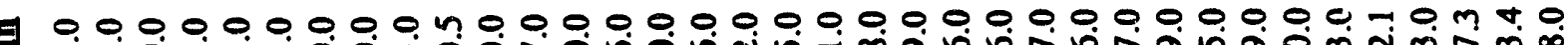

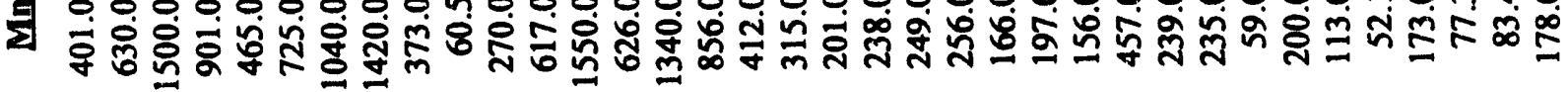

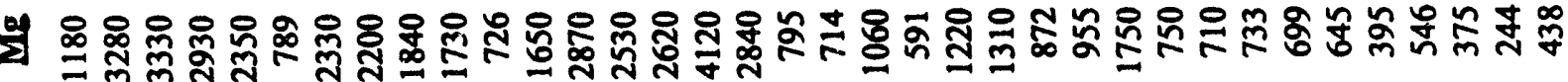

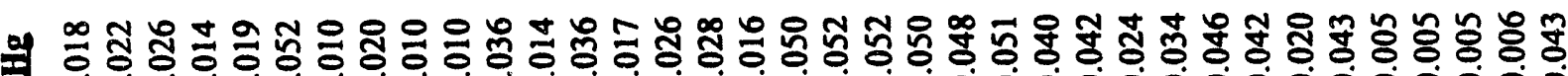

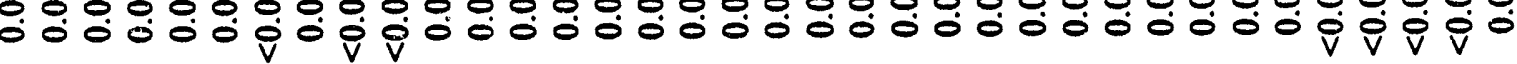

ปै $\vee \vee \vee \vee v \vee v$

E

즐 -

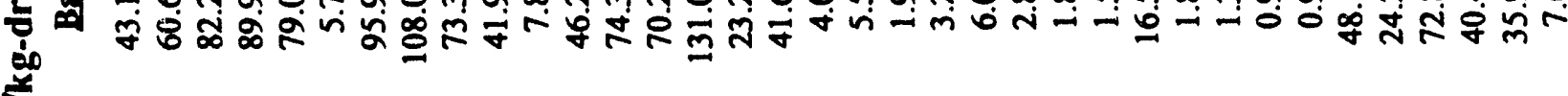

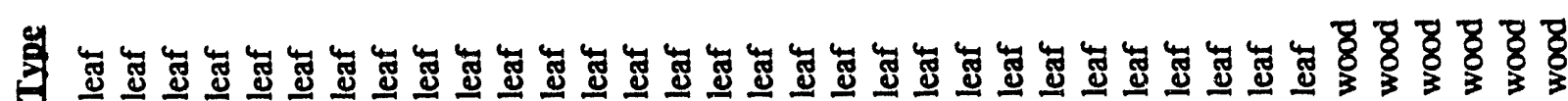

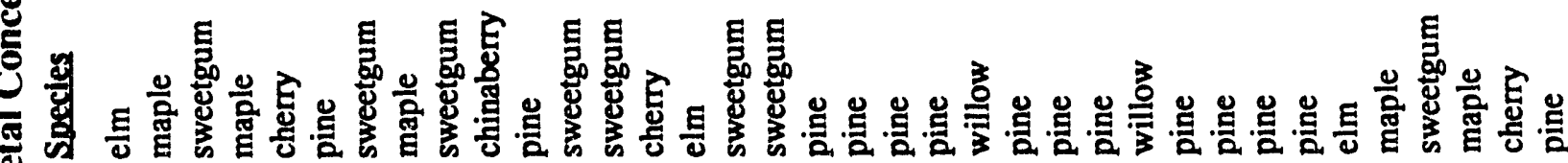
$\sum$

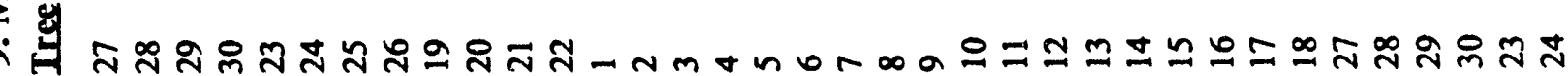




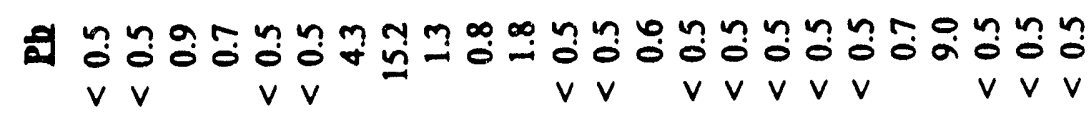

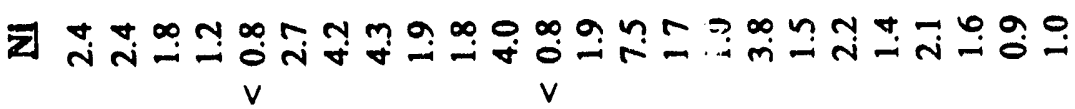

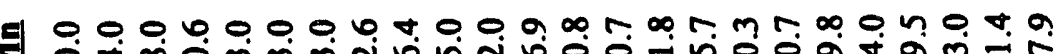

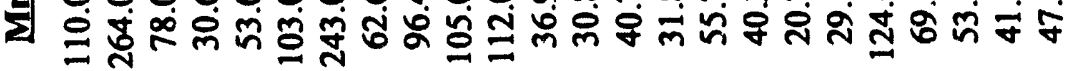

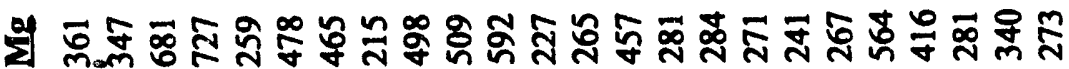

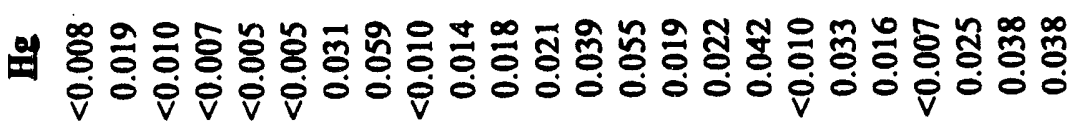

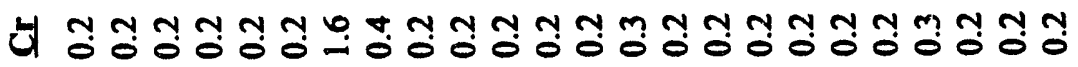
$v v v v v v \quad v v v v v \quad v v v v v v v v v$

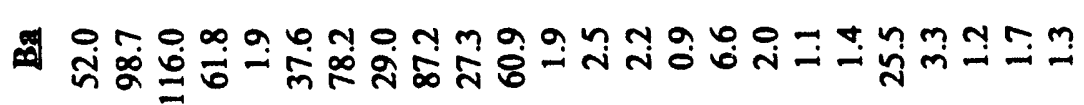

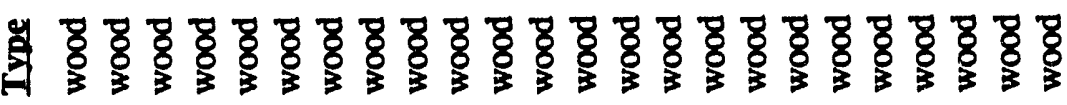

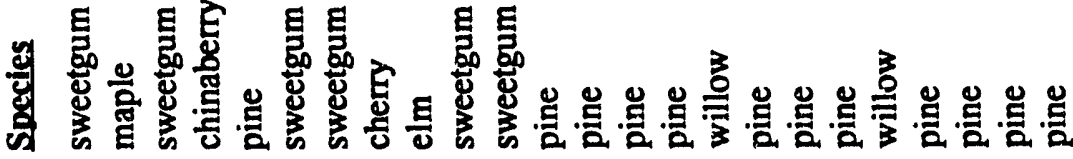

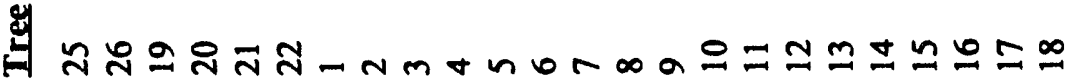

변

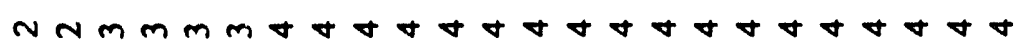



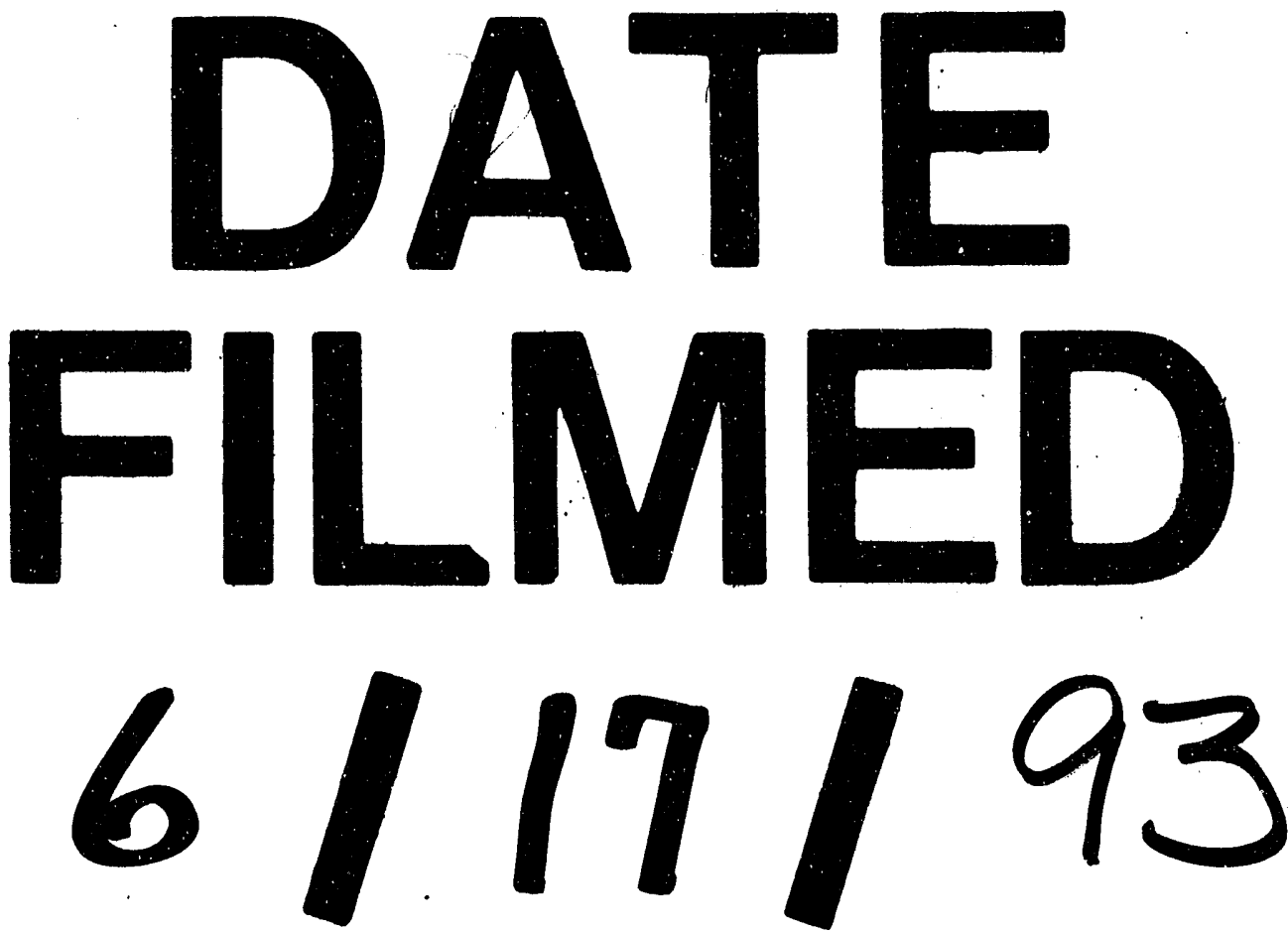
